\title{
Lead isotopic composition in the geochemical reference rock $\mathrm{JG}-1$
}

\author{
Hiroshi ShIRahata \\ Muroran Institute of Technology, 27-1 Mizumbto, Muroran 050, Japan
}

The isotopic composition of lead in the geochemical reference rock JG-1 (granodiorite), which was prepared and distributed by the Geological Survey of Japan, was determined in this study by surface ionization mass spectrometry using ultra-clean analytical techniques. A large numbers of data on the concentrations of trace metals in the JG-1 reference sample was compiled and in many metals the concensus means and/or average values were given by Ando et al. (1974). The JG-1 is available as a reference material for concentration measurements of many elements in silicate rocks and it would be advantageous to use this reference sample for isotopic analyses as well. Isotopic compostions of metals in this standard rock have been reported for strontium, whose $87 / 86$ ratios determined by several investigators agree with each other within analytical errors (Ando et al., 1974). In order to obtain reliable isotopic composition data of lead in rocks and minerals which contain $\mathrm{Pb}$ concentration levels of $\mu \mathrm{g} / \mathrm{g}$ or less, it is necessary not only to accurately measure its ratios but also to practice strict contamination control during sample preparation by using the clean analytical techniques in a clean laboratory. It should be realized that there may be a significant error in isotopic $\mathrm{Pb}$ data because of artificial lead contamination to a sample by the blanks from reagents and laboratory equipment used, by $\mathrm{Pb}$ aerosol in a room and by the analyst himself through handling and analytical processes if he treats it with conventional chemicals and articles in an ordinary laboratory. The isotopic composition of lead in JG-1 presented here was determined using a high resolution surface thermal ionization mass spectrometer and microanalytical methods of strict contamination control at ultra-clean laboratory.

\section{Sample preparation and chemical analysis}

An aliquot of rock powder of the JG-1 (split 7 position supplied by the G.S.J.) was taken and finely ground in an agate mortar, which was washed before with dilute hydrofluoric acid, nitric acid and doubly quartzdistilled water (QDW) at a clean laboratory at the Muroran Institute of Technology. The fine powder was stored until further aliquotting in an acid-cleaned (Patterson and Settle, 1976a) polyethylene bottle which was triple wrapped with acid-cleaned polyethylene bags to keep it free from lead contamination.

Chemical separation and purification of lead in the sample was carried out at the ultra-clean laboratory of Dr. C.C. Patterson at the California Institute of Technology. A 
20 to $50 \mathrm{mg}$ aliquot of the material in the bottle was placed into an FEP teflon beaker using a stainless steel spatula cleaned with hot nitric acid. A mixture of $\mathrm{HNO}_{3}, \mathrm{HClO}_{4}$ and $\mathrm{HF}$ was added to the sample. The beaker was covered with a teflon watchglass and stood at room temperature for several hours. Then the beaker from which the cover was removed was placed in a TFEteflon oven flushed with filtered nitrogene gas, and was heated until strong humes of perchloric acid formed. One milliliter of $\mathrm{HF}$ was added to the sample which was then evaporated to dryness. The residue was twice redissolved with conc. nitric acid and evaporated again to convert any perchlorates to nitrates, then redissolved in dilute nitric acid, and transferred into a teflon separately funnel. The lead from this aqueous solution was extracted into a dithizone-chloroform solution at $\mathrm{pH} 9$ in the presence of both $\left(\mathrm{NH}_{4}\right)$ citrate and $\mathrm{KCN}$. The separated chloroform layer was washed with slightly ammoniated QDW and backextracted with dilute nitric acid. The sample solution was further purified by repeating the extraction procedure and dithizone traces were removed from the aqueous phase by washing it with $\mathrm{CHCl}_{3}$. The final solution was drained into an FEP beaker, evaporated to dryness inside a teflon oven in an atomosphere of pure $\mathrm{N}_{2}$. The remaining spec of sample residue was dissolved with several $\mu 1$ of QDW and loaded onto an outgassed rhenium filament with silica gel and phosphoric acid for analysis in a mass spectrometer.

Prior to the extraction procedure, the separately funnel used was preconditioned by extracting the QDW, adjusted to $\mathrm{pH} 9$, with $\mathrm{Dz}_{-} \mathrm{CHCl}_{3}$. This particular step reduces effectively the level of the $\mathrm{Pb}$ blank contributed by the funnel (D. Settle, personal communication, 1980). The level of artifact $\mathrm{Pb}$ contamination from teflon containers and transfer quartz pipettes used is largely lowered by soaking them for several days in three acid baths which contain concentrated analytical grade, $1 \%$ triply distilled, and $0.1 \%$ purest nitric acids, respectively (Patterson and Settle, 1976a). Throughout the sample preparation and analytical processes the laboratory articles were touched and handled only with untalced polyethylene gloves. As a result of these and other measurements of contamination control (Patterson and Settle, $1976 \mathrm{a}, \mathrm{b})$, the total procedural contamination of lead was evaluated to be insignificant with respect to samples containing tens of ng of $\mathrm{Pb}$ or more: the overall contamination effects are estimated to be less than $1 \mathrm{ng} \mathrm{Pb}$.

\section{Mass spectrometry and results}

A high resolution surface thermal ionization mass spectrometer equipped with an automatic digital reading and computation system was used to determine the $\mathrm{Pb}$ isotopic composition at the Caltech laboratory. Isotope ratio determinations of 206/208, $206 / 207$ and 206/204 were made at three different filament temperatures. At a given filament temperature sets of ten peak hight measurements (10 seconds integration time during scanning) were done, first for the ratios of $206 / 208$ and 206/207, subsequently for 206/204. Baseline readings were taken immediately before and after each data set. The mean ratios were corrected for shunt errors and for velocity discrimination effect (root mass) since an electron multiplier was used. The isotopic ratios of lead in the reference material were calculated for each analysis by averaging the corrected means of these data sets. 
Table 1-a Lead isotope ratios of the JG-1 rock standard, obtained by five individual analyses

$\begin{array}{ccccc}\text { Sample size(mg) } & \text { Sample run } & 206 / 208 & 206 / 207 & 206 / 204 \\ 48 & 1 & 0.48130 \pm 0.000145^{*} & 1.1914 \pm 0.00046^{*} & 18.479 \pm 0.0382^{*} \\ 29 & 2 & 0.48084 \pm 0.000121 & 1.1907 \pm 0.00097 & 18.450 \pm 0.0337 \\ 36 & 3 & 0.48095 \pm 0.000101 & 1.1915 \pm 0.00009 & 18.490 \pm 0.0152 \\ 22 & 4 & 0.48102 \pm 0.000117 & 1.1918 \pm 0.00035 & 18.515 \pm 0.0128 \\ 31 & 5 & 0.48077 \pm 0.000206 & 1.1908 \pm 0.00070 & 18.496 \pm 0.0240 \\ & \text { mean } & 0.48098 \pm 0.000205 & 1.1912 \pm 0.00047 & 18.486 \pm 0.0240\end{array}$

* Standard deviation (2o).

$\begin{array}{ccc}\text { Table 1-b } & \text { Calculated ratios } \\ \text { Sample run } & 207 / 204 & 208 / 204 \\ 1 & 15.510 & 38.393 \\ 2 & 15.495 & 38.371 \\ 3 & 15.518 & 38.444 \\ 4 & 15.536 & 38.492 \\ 5 & 15.533 & 38.471 \\ \text { mean } & 15.518 \pm 0.0168 * & 38.434 \pm 0.0512^{*} \\ \text { Standard deviation }(2 \sigma) .\end{array}$

Five aliquots of the powder (20 to 50 $\mathrm{mg}$ each) were individually processed and analyzed within a couple of weeks. The results obtained are listed in table 1-a. In most sample run the ratios $206 / 208$ and 206/207, and 206/204 were determined with a precision better than $\pm 0.06 \%$ and $\pm 0.1 \%$ in relative standard deviation $(2 \sigma)$, respectively. The table $1-b$ represents the $207 / 204$ and 208/204 ratios calculated from the data given in the table 1-a. In spite of relatively small sample sizes, the isotope ratios obtained in five individual experiments were in good agreement. The average isotopic composition of the reference sample and the overall limit of uncertainty $(2 \sigma)$ are given in the bottom line of table 1-b. The result presented here suggests that even if an aliquot of tens of $\mathrm{mg}$ is taken from a sample powder to be analyzed, it would be able to precisely determine its
$\mathrm{Pb}$ isotope ratio if the sample material is reduced very finely, mixed thoroughly and treated chemically in lead contamination free environment, and that the $\mathrm{JG}-1$ sample can be used as a suitable reference material for evaluating an analytical method, from sample preparation through mass spectrometer run, employed to measure isotopic composition of lead in a given silicate rock sample.

I am indebted and sincerely grateful to Dr. Clair C. Patterson at the California Institute of Technology for allowing me to use his ultra-clean laboratory and mass spectrometer, and for his helpful advice and critism. Thanks are also due to Dr. Bernhard Schaule for reading the manuscript and to Dorothy M. Settle at Caltech for profitable suggestions. The reference standard used in this study was provided by 
Dr. Ando of the Geological Survey of Japan. This work is partly supported by the Toyota Science Fund (Grant 79-1-092).

\section{Reference}

Ando, A., Kurasawa, H., Ohmori, T. and Takeda, E. (1974), 1974 compilation of data on the GSJ geochemical reference samples JG-1 granodiorite and JB-1 basalt. Geochem. J., 8, 175192.

Patterson, C.C. and Settle, D.M. (1976a), The reduction of order of magnitude errors in lead analyses of biological materials and natural waters by evaluating and controlling the extent and sources of industrial lead contamination introduced during sample collecting, and analysis. National Bureau of Standars Special publication, 422, 321-351.

Patterson, C.C. and Settle, D.M. (1976b) Comparison of isotope dilution mass spectrometric techniques with relative to analytical methods for the analysis of trace metals in bioligical materials. Proceedings of the 7th International Mass Spectrometry Conference, Florence, Italy, Aug. 30-Sep. 3, 1976.

\section{地球化学的標準岩石 JG-1 の鉛同位体比}

白幡 浩 志

厳密に重金属污染が制御されたクリーン害験室で地球化学的標準岩石 JG-1 (Split 7 position) 中の鉛を抽出・ 精製し、レニウムシングルフィラメントにシリカゲル及びリン酸とともに塗布後，高分解能表面電離型質量分 析計で同位体比を測定した。全分析操作を通じ試料への鉛污染量は $1 \mathrm{ng}$ 以下に保たれた。20〜50 mgずつ分取 した 5 粉末試料の鉛同位体比は変動保数約 $0.1 \%$ 以内で一致した。得られた同位体比は次の通りである：

$206 / 204 ; 1.8486 \pm 0.0240 *$ ，207/204; 15.518 $\pm 0.0168 ， 208 / 204 ; 38.434 \pm 0.0512$,

$206 / 208 ; 0.48098 \pm 0.000205,206 / 2071.1912 \pm 0.00047$

*standard deviation $(2 \sigma)$ 。 